\title{
Homeobox Protein Meis1
}

National Cancer Institute

\section{Source}

National Cancer Institute. Homeobox Protein Meis1. NCI Thesaurus. Code C26382.

MEIS1 Homeobox Protein Homeobox protein Meis1 (390 aa, $43 \mathrm{kDa}$ ) is encoded by the human MEIS1 gene. This protein plays a role in transcriptional regulation in hematopoietic and vascular cells. 